\title{
GAS, GRASS OR ASS, NO ONE RIDES FOR FREE: THE MOHAWK MAYOR
}

\author{
REBECCA CASSON
}

\begin{abstract}
In November 2013 Darryn Lyons, a former celebrity photographer wellknown for his colourful antics, was directly elected as mayor of Geelong, the second largest city in the State of Victoria, Australia. Also known as "Mr Paparazzi" and "The Mohawk Mayor", Lyons's leadership lasted just 30 months before the Victorian State Government sacked him and dissolved the entire Geelong Council, revealing a pre-existing culture of bullying that appeared to be compounded by Lyons's celebrity persona. How did Lyons's persona affect Geelong's newly established procedures for a directly elected mayor? Drawing on one particularly controversial incident, and using data collected from Lyons's autobiography, together with media articles, official documents and social media, this article discusses how - as a celebrity politician - Lyons appeared to be unable to effectively separate his celebrity persona from his public persona. This seemed to drown out Geelong's important issues, and undermined the legitimacy of local government. The current literature on directly elected mayors does not include consideration of how electing a celebrity as mayor complicates the problems of legitimacy in local government, and there is a paucity of literature on directly elected celebrity mayors in Australia. An emerging literature on directly elected mayors primarily addresses problems with legitimacy in contemporary politics, while the literature on how celebrity politics is changing legitimacy has been well established. Using the Lyons case, this article examines both literatures and contributes to the national and international debate on directly elected celebrity mayors.
\end{abstract}

\section{KEY WORDS}

Celebrity politics, populism, legitimacy, directly elected mayors, Darryn Lyons, Geelong

\section{INTRODUCTION}

On 25th November 2013 Darryn Lyons, well-known as a former owner of an international photography agency in London, won the ballot to become the second directly elected mayor of the City of Greater Geelong (CoGG). At that time, Geelong was undergoing an economic transformation from a manufacturing base to a service-centred economy, and consequently was set to suffer a net loss of more than 1000 jobs during Lyons's term of office. As a result of his celebrity persona, Lyons was one of the most prominent directly elected celebrity mayors in Australia. Lyons's leadership lasted until April 2016 when, following a Commission of Inquiry by the Victoria State Government, the entire council was sacked. This article takes up a case study of one controversial incident over the Madonna t-shirt Lyons wore when he was mayor - at Oktoberfest, a local beer festival. 
The case study highlights two issues that raise questions about Lyons's mayoral authority. First, there was the suggestion of a conflict of interest - especially as Oktoberfest had been organised by Lyons's company and he was a major private backer. Second, there was Lyons's controversial behaviour and perceived inability to effectively separate his celebrity persona from his public persona. This seemed to drown out Geelong's important issues and undermined the legitimacy of local government. This article has three parts. First, in order to situate the article and its analysis, I examine the literature on local government, directly elected mayors, celebrity politicians and populism. Second, I present Lyons's "complex character" through a framework of his personal and career history (Lyons 18). Third, I make my primary empirical contribution by analysing data collected from Lyons's autobiography, Mr Paparazzi, together with media articles, official documents and social media. This analysis sheds light on the "framing" of the t-shirt incident, as set out by Barnett in his theory of "framing" in reference to media and politics.

\section{DIRECTLY ELECTED CELEBRITY MAYORS: THEORETICAL FRAMEWORK FUSION}

In this section, I examine the separate literatures of celebrity studies and political science. These literatures are key to this article, as current investigations of directly elected mayoral structures in local government do not include consideration of how electing a celebrity as mayor affects legitimacy. Local government has substantive legitimacy in its immediate community, but it is the state or central government that has formal power to replace it with a different system (Casson; Kavanagh et al.; Leach, Coxall and Robins). This is what happened to Lyons and the CoGG, regardless of the fact that the mayor had been directly elected by the "the people" of Geelong (Moffitt and Tormey 389).

Both the system of local government and the way that mayors are elected differ across the globe. Generally, mayors can be (1) elected by peers on council: a "first among equals" and (2) directly elected by "the people". This article focuses on the latter. Directly elected mayoral systems have become an increasingly common feature of local government throughout developed democracies, and further research is required to examine their effectiveness (Elcock). There is some examination on the legitimacy of directly elected mayoral models (Copus; Copus; Fenwick; Travers; Campus and Pasquino; Game; Rallings; Rao; Mouritzen and Svara) but there is a lack of empirical evidence about them (Sansom; Martin and Aulich; Warwick Commission). Specifically, Australia has attracted limited attention (Sansom).

Australia's federal system of government allows states to operate different directly elected mayoral models, and these variations have resulted in diverse discourse (Grant, Dollery and Gow; Dollery and Marshall; Grant, Dollery and Kortt; Worthington and Dollery; Power, Wettenhall and Halligan; Sansom; Martin and Aulich; Grant, Ryan and Kelly). Although the Australian Labor Party (ALP) first introduced directly elected mayors to Australia in 1915, the system operates in less than 40\% of councils (Sansom; Grant, Dollery and Kortt; Power, Wettenhall and Halligan; Tucker). In Victoria until recently, and with the exception of Melbourne, all mayors had been elected first among equals. Regional councils have had no system of direct election through referendum. However, in October 2012, the people of Geelong directly elected their mayor for the first time. This new system represented a change in the way local government operated in regional Victoria and makes Geelong an important case study especially in relation to celebrity politics.

The definition of a celebrity politician's persona can be drawn from both political science and celebrity studies. In political science, the closest definition of a directly elected celebrity mayor is the "saviour": "charismatics who forcefully impose their will upon what 
might seem to be a rudderless populace" (Warwick Commission (33). Grant, Dollery and Kortt also cite the "novice mayor" phenomenon; an "outsider" or "new blood", directly elected by popular vote, who can better "fix the perceived problems" of local government than "rusted on" councillors (Grant, Dollery and Kortt 8). The "saviour novice" term can therefore be derived from political science to describe directly elected celebrity mayors.

Drawing from the populism literature, Moffitt and Tormey's theory of populism as a "political style" is developed from their suggestion that populism is a style that is performed and enacted. This has resulted in contemporary politics being intensely "mediatised" and "stylised" (Moffitt and Tormey 390). Moffitt and Tormey's framework - appeal to "the people"; crisis, breakdown, threat; and "bad manners" in politics - is particularly relevant to this article (Moffitt and Tormey 382). They argue that populists' appeal comes from their disregard for "appropriate" ways of acting in the political realm - and specifically by gaining attention for their "novel stylistic features", rather than for their "traditional content" (Moffitt and Tormey 388). These politicians display a certain political style, which they claim makes them distinct from the elite. This can take many forms, including being overly demonstrative and "colourful" in their use of fashion. It also relates to bad manners such as the use of gestures, slang, swearing and political incorrectness (Ostiguy; Moffitt and Tormey). The archetypal trickster character is also relevant here. Known for amusing the public the way a jester entertained in historic kingdoms, tricksters cross boundaries and break common conventions (Metman; Hyde). In Lyons's case, he scorned authority and used an anti-politics platform to present himself as both a "saviour" and a trickster (Layard 108).

Within celebrity studies, the concept of celebrity is described by P David Marshall (Celebrity) as a system for valorising meaning and communication. It confers on a person a free power to be a voice above others by being regarded as legitimately significant. There is much discourse on classifications of celebrity politicians (Marshall Celebrity; Wheeler; Mukherjee; ' $t$ Hart; Boykoff; Marsh, 't Hart and Tindall) and specific frameworks have identified a range of "celebrity politico" categories (West and Orman; Marsh, 't Hart and Tindall). Street has argued for a reduction to two: (CP1) a politician who used to be a celebrity (for example, Arnold Schwarzenegger or Ronald Reagan); and (CP2) a celebrity who seeks to influence politics by way of their fame and status (for example, Bono or Bob Geldof). More recently Wood, Corbett and Flinders suggest distinction between "superstar celebrity politicians" (SCPs) and "everyday celebrity politicians" (ECPs) for further distillation (Wood, Corbett and Flinders 583). With regards to Lyons, I have utilised all three elements: CP1, ECP and - more specifically - the famed non-politico:

Known in fields outside of politics before they run for elective office. They are responsible for their own prominence and transpose fame in one sector onto political life. They can be seen as political 'white knights'. They have a high degree of public trust worthiness and star power. They are used to the public spotlight and dealing with media coverage, fans, gossip columnists and intrusions into their private lives, making their entry into a regime based on celebrity politics easier for them to handle. They are confident about their own fame and fortune. (West and Orman 2-4)

As this article focuses on Australian celebrity, it is important to understand the condition of celebrity status within Australia. Australia's celebrity data was previously dependent on American and British based organisations, but there has been a major shift in how it now operates, and a bespoke publicity industry has begun. This change has enabled lowerlevel celebrities, such as Lyons, to emerge more prominently within the Australian celebrity scene, and more easily enter into the political arena (Turner, Bonner and Marshall). In this 
context, only one directly elected Australian celebrity mayor, Bertrand Cadart, possesses a specific celebrity resume similar to Lyons. There are obvious cases in the literature of directly elected celebrity mayors in major cities, such as Arnold Schwarzenegger. However, with the exception of the work by Asquith and Stoker, there is limited discourse on directly elected celebrity mayors from local government in second-tier cities. This is interesting because people living in a second-tier city, and particularly those in former manufacturing centres with unemployment and social problems, may be more prone to the populist appeal of a celebrity mayor. This overall lack of empirical data limits our understanding of celebrities making good mayors. Further investigation is required to ascertain the full effects of celebrities permeating into local government politics, and specifically in Australia. This article begins that task.

\section{Mr PAPARAZZI: The COMPLEX PERSONA}

In this section, I examine Lyons's personal history, investigate the layers of his complex character and shed light on his business and celebrity status. First, it is important to define the two main terms used in this article to analyse Lyons's characteristics:

- Celebrity Persona: Lyons had a pre-existing celebrity persona when he was appointed as mayor, and this can be defined by him being a "model for emulation", galvanising "issues in popular culture" and affecting "public opinion" (Rojek 26).

- Public Persona: Lyons's public persona can be defined as his "public self" or "mask" that society sees, particularly through his civic role as mayor. It is important to note that news and journalism are "explicitly and implicitly involved" in the exposure of both celebrity and public personas (Marshall "Persona Studies" 154; Jung)

While the above two terms are the main definitions used in this article, there is another definition that is also important to consider:

- Private Self: Lyons's private self can be defined in three parts (i) his private commercial operations versus his civic role (ii) his human and vulnerable private self, with the elements of his life and true feelings that are known only to him (Cohen) and (iii) Lyons's illusory private self, which is displayed within his celebrity persona and revealed through both his "confessional" autobiography and exhibited on reality TV shows (Cohen 141).

These definitions provide clarity that Lyons's celebrity and public personas, together with his private self, appear to be a "conscious act" requiring "careful staging" (Marshall "Promotion" 39; Goffman).

In order to fully investigate the effect these personas had on Lyons's role as mayor, it is first relevant to consider that Lyons favours brightly dyed hair shaped into a mohawk, flashy clothes and mirrored sunglasses (Colquhoun). Lyons had "an idyllic childhood in Geelong", being raised in a strict Baptist middle-class family (Lyons 9). Lyons attended East Tech Secondary school and broke with his family's tradition when he developed a passion for photography. Lyons loves a drink and this came to the fore when he lost his licence for "drink driving" (Lyons 20). Using this as a catalyst to begin his global career ambitions, Lyons left Geelong for London at the age of twenty-two and secured roles with various newspapers (Lyons). Lyons soon rose through the ranks and later founded his company Big Pictures, which supplied paparazzi-style photography for news organisations. 
Lyons first gained widespread media attention when Big Pictures sold the photo that led to the News of the World exposé of David Beckham's alleged affair with his personal assistant (Urban). Subsequently, and as a result of his paparazzi business, Lyons frequently appeared as a media commentator on radio and television. However, his main entrée to the celebrity world came through his appearance in the BBC's Mr Paparazzi, a fly-on-the-wall documentary about Lyons which attracted 6.5 million viewers (Lyons). Lyons's "persona as a naughty boy involved in naughty business" seemed to be very popular with the public and he subsequently appeared on various UK and Australian reality TV shows, including Big Brother, Excess Baggage and Dragon's Den (Lyons 266).

Lyons relished the celebrity lifestyle that brought him wealth and luxury items such as a private yacht and jet, all of which made him feel that he had "made it" (Lyons 258). However, Lyons's celebrity status also introduced him to the rock star lifestyle. He became addicted to cocaine, binge drinking, and gambling: "everything I could do to damage myself. I really hit the self-destruct button. I was living in a 'white cloud' of my own creation" (Lyons 128-29).

Suffering from depression, Lyons took remedial action when he woke with his pillow soaked in blood from a nose bleed and was unable to move (Lyons). He temporarily returned to Geelong to confess to his parents and go "cold turkey" (Lyons 131).

In terms of characteristics, Lyons acknowledges that there are differences between him and most other people but he does not seem to grasp that these are interrelated with his celebrity status (Lyons). For example, Lyons denies his own celebrity: "I don't see myself as famous, I love the attention at times. Of course, I am easily identifiable. There aren't too many peacocks like me around, so I make a simple target" (Lyons 276). This perceived superficial denial is interesting. Lyons does not "see himself" as famous but he knows he is.

Lyons's controversial personality is well documented and shows one side to him. However, as indicated in the multiple facets of his "personal self" above, there is another side to his personality that is often unseen. Lyons's human and vulnerable private self is specifically perceptible from his autobiography, and is completely separate from his illusory private self. For example, Lyons admits that he finds it hard to dismiss employees unless he does so in a rage or temper: "I always get someone else to do it because I get quite emotional" (Lyons 302). It would appear that, as a coping mechanism, Lyons has gradually separated his celebrity persona, public persona and illusory private self from his actual private self: "I became unemotional. I am not saying that distancing yourself from your feelings is a good thing" (Lyons 39), but it was how he coped. Nevertheless, Lyons's celebrity persona appears to be confronting for many in a corporate context. For example, Lyons's staff established coping mechanisms to manage the effects his personality had on business operations:

I'm a very loving guy, but I can be difficult to work for...when I visit...they (staff) have to mentally prepare themselves. Anyone who hasn't met me has to be given a briefing before I get there and warned not to take anything personally. Some people just don't get me. In fact, at times I don't even understand myself! (Lyons 120)

It would seem that this aspect would also come to bear when Lyons was the mayor of Geelong, and the CoGG bureaucracy developed strategies to manage his behaviour. Lyons claims that his personality has evolved and softened over time: "I used to be the biggest shouter, stamper and screamer. I used to throw chairs. I was a rock-star boss...these days I am much shrewder, much more of a thinker" (Lyons 291-92). However, Lyons's behaviour did not appear to change when he was mayor, and this may be seen to have contributed to his sacking from the CoGG. For example, Lyons admitted that he had made council staff so intimidated that they had to be physically relocated away from the mayoral offices to a different part of the building: "I' $m$ the 
first to admit that my razzamatazz and in-your-face style has not been to everyone's liking and I've stepped on a few toes" (Kurmelovs). In Lyons's case, these expressions of anger seemed to be an indicator that his celebrity persona may have been incompatible with the mayoral role, rather than an indicator of leadership or "power" (Campus 58-59).

Lyons admits that he is not a businessman and struggles with commerce (Lyons). His opponents raised this during the mayoral campaign, arguing that Lyons's UK-based company had gone into administration and then liquidation owing money to employees and creditors. (Lander). Following this, Lyons moved back to Geelong and, on 10th October 2013, officially declared his candidacy to become Geelong's mayor. Lyons said that: "Every election needs a comedy candidate" and "[using Prime Minister Tony Abbott's example] that the electorate respects a man with great abs" (Millar). Lyons promised to cut red tape, beautify and rejuvenate central Geelong, promote the Bellarine Peninsula and make savings in the CoGG's bureaucracy (Moore).

Lyons leveraged his celebrity persona and social media presence for his campaign. He had more than 717,000 Twitter followers at that time, which was much more than his competitors (Millar). As a result, Lyons garnered almost $30 \%$ of the first-preference votes and the win gave him a clear mandate. At the end of his first three months as mayor, Lyons issued a "100 days of action" report using the official CoGG logo. This report claimed that more than 75 million people had received tweets about Lyons and the CoGG in his first 100 days as mayor, and he had reached an estimated total of 11 million people on Facebook (City of Greater Geelong). The document also claimed that the media attention Geelong received in Lyons's first 100 days was estimated to be worth over \$15.6 million (City of Greater Geelong). These figures were calculated for the CoGG by an independent media analysis company.

Lyons quickly appeared to stamp his celebrity persona on the mayoral role by staying in luxury hotels and purchasing personalised accoutrements. In the first seven months, Lyons claimed AUD\$9,000 worth of expenses for stays in first-class hotels, accessories for his electronic devices, fountain pen refills, shirts to wear under his mayoral robes, and chauffeur driven cars. He also billed ratepayers for a "Mayor Darryn Lyons" signature stamp, special engraving for the mayoral pen and designed a regal range of mayoral merchandise - including dressing gowns, towels, luggage, shirts, vests, caps, flags, banners and stationery - and there was even a mayoral lollipop (Hurley; Squires). Lyons was also photographed in a range of "celebrity" settings throughout his mayoral term, including one controversial image of him wearing full mayoral regalia crouched at the feet of his fiancée who was clad only in pages of the Geelong Advertiser and Glad Wrap. Lyons also behaved in a way never seen before at the CoGG such as missing council meetings to attend the races (Squires).

The blurring of Lyons's celebrity persona with his public persona can be seen through his use of social media during his time as mayor. The opinions Lyons expressed through his personal Twitter account would often be re-tweeted via the official mayoral Twitter account. It could also be perceived that Lyons was able to use his mayoral position to promote his private business interests. For example, in the lead up to Oktoberfest, Lyons tweeted adverts from his personal Twitter account about the event using an image of himself dressed in lederhosen: "Perfect day for Oktoberfest Geelong!!! Get down tiks on sale at the door Geelongracingclub now don't miss out!!!" (Lyons). This was despite the fact that Lyons would later open the event in his official capacity as mayor. Whilst it was evident that Lyons was willing to undertake publicity stunts and "do anything, as long as it's all about Geelong" (Colquhoun), it could be argued that he struggled to effectively manage interaction between his celebrity persona and his public 
persona. The case study below demonstrates how this may have contributed to Lyons's downfall as a directly elected celebrity mayor.

\section{CASE STUDY: GAS, GRASS OR ASS, NOBODY RIDES FOR FREE}

On 10th October 2015, Lyons opened Oktoberfest in his official capacity as mayor, wearing the mayoral robes with jeans. However, according to Lyons, he became hot at the festival and went home to change, selecting a t-shirt from an old box he had not opened for more than two decades (Miletic). The controversial t-shirt had a full-frontal naked image of the pop star Madonna hitchhiking, wearing only high-heeled shoes, and carrying a sign with the obscene slogan: "Gas, grass or ass, no one rides for free". Lyons then returned to the festival, and images of him wearing the t-shirt soon emerged on social media.

Through a range of tweets, Councillor Jan Farrell - head of the CoGG's women's advisory committee - criticised Lyons for wearing the t-shirt and started a social media storm: "This is what passes for leadership at Geelong. As a woman who lives and works in Geelong I am beyond offended at his ongoing disrespect for women. Our 'mayor' in a disgusting tee shirt at Oktoberfest...such an abysmal role model for the young men he meets" (Farrell; Miletic). Commentary on social media quickly elevated the story from local to national and international news. However, even though there was an opportunity to discipline Lyons for wearing the tshirt, the CoGG did not take action against him (Dundas). This highlights that, while the slogan on the t-shirt was inappropriate for a mayor to wear, Lyons had not acted illegally by wearing it. Nevertheless, the question emerged: was Lyons performing his bad boy persona, as described above, knowing full well how people would respond, or did he act carelessly and make a mistake?

\section{Methodology: Data Analysis and Framing}

In this section, I outline the methodology used to analyse the case study data and, specifically, "framing" as a theoretical framework. "Framing" is a common form of analysis in cultural and media studies, but the analysis here follows Barnett's presentation of the theory to make sense of the particular slants, themes and language invoked in media coverage of politics (Barnett; Wright and Holland). Framing is a way of examining how an incident is discussed, described and debated, helping to shape the construction of an issue and particular representations. Frames are a way of portraying a subject to encourage specific interpretations, while discouraging others. Framing is therefore an appropriate structure for this article, because how a conversation is framed makes a big difference to how it is understood.

Before going further into framing, let me outline how I gathered information and formed two specific data sets:

- Data set one - I analysed media coverage of the t-shirt incident from a range of local, national and international newspaper articles, together with content from social media. First, my search criteria specified articles must mention Lyons and refer to the t-shirt incident. Second, articles were selected from a range of media outlets and social media. Third, articles were limited to the eight weeks following the t-shirt incident.

- Data set two - In order to test the "framing" from data set one, I also analysed online comments made in response to two specific media articles. First, I used comments relating to an online poll conducted by the Geelong Advertiser which posed the question: did Darryn Lyons go too far wearing a t-shirt demeaning women under his mayoral robes at his new beer festival? (Papps). Second, I used online comments 
responding to a Herald Sun article by Susie O'Brien - an Australian columnist and blogger - which had attracted a similar number of comments.

As News Corp owns both the Geelong Advertiser and Herald Sun, I acknowledge that media ownership may have an impact on the results. I then categorised the information gathered from each data set into two groups (a) those comments that were either supportive of Lyons, or were critical of the issue being sensationalised and (b) those comments that were critical of Lyons wearing the t-shirt.

How did Lyons fare in these sets of comments?

Table 1: Data from media source

\begin{tabular}{|l|c|c|c|}
\hline Media source & $\begin{array}{l}\text { Number of } \\
\text { responses }\end{array}$ & $\begin{array}{l}\text { Supportive of Lyons } \\
\text { wearing the t- } \\
\text { shirt/critical of the } \\
\text { issue being } \\
\text { sensationalised }\end{array}$ & $\begin{array}{l}\text { Critical of Lyons } \\
\text { wearing the t-shirt }\end{array}$ \\
\hline $\begin{array}{l}\text { Geelong Advertiser } \\
\text { poll results }\end{array}$ & unpublished & $47 \%$ & $53 \%$ \\
\hline $\begin{array}{l}\text { Geelong Advertiser }- \\
\text { published responses }\end{array}$ & 48 & $60 \%$ & $19 \%$ \\
\hline $\begin{array}{l}\text { Herald Sun online } \\
\text { comments }\end{array}$ & 42 & $81 \%$ & $40 \%$ \\
\hline
\end{tabular}

A range of relevant and important themes have emerged from my analysis including feminist and libertarian frames, decorum, gender, commercial opportunism versus collective responsibility, and the local versus the national. There are many dimensions of this case study that warrant further research but, due to limited space, I have chosen to use an intentional versus unintentional analysis structure. This aspect is most pertinent to the issue of how Lyons managed interaction between his celebrity persona and his public persona:

1. As an intentional act; a celebrity politician acting unacceptably, outside the bounds of normal political respectability, in order to get attention - displaying bad manners as described by Moffitt and Tormey - alongside the celebrity notion that all coverage is good coverage. In this frame, Lyons appears to know exactly what he is doing; the act is perceived to be politically calculated and designed to shock and garner publicity.

2. As an unintentional act; a demonstration of Lyons's perceived lack of judgment and character. In this frame, Lyons does not seem calculating, and this type of behaviour is needed to make politics 'real'.

These frames are important for two reasons. First, they help to narrow the analysis of responses, allowing us to ignore for example wider politicking, party political infighting, and attempts to win voter support. They focus our attention on whether the t-shirt incident was a genuine mistake or a miscalculated manoeuvre for political gain. Second, these frames direct attention towards finding reasons why Lyons's persona may have been incompatible with the mayoral role (Wright and Holland). Given his celebrity status and anti-politics platform, Lyons was held to a higher governance standard. He was expected to clean up politics by acting for the 
non-elites of Geelong and showing a new form of leadership. Nevertheless, it could be argued that wearing the controversial t-shirt was exactly how Lyons acted for the non-elites, and offered a new form of populist leadership. Regardless, the framing of the $t$-shirt incident simultaneously presented Lyons's celebrity persona, exposed his illusory private self and appeared to show his public persona in a negative light. In this situation, Lyons did not seem to 'do' celebrity very well, and gave the impression that he had neglected the specific demands placed on him as mayor (Wright and Holland). In effect, although Lyons was performing well as a disruptive celebrity politician, he contravened the expectation of due decorum as mayor.

\section{An Unintentional Act}

"I am not apologising for wearing the t-shirt, but I've made a mistake in I didn't realise what was written on the t-shirt, I just thought it was just graffiti. For everyone that this has upset I certainly apologise. I had no idea the wording on it and that's the God's honest truth. I swear on my grandmother's grave. I certainly didn't wish to demean women in any shape or form and I certainly wouldn't do that." (Cannon 4)

Lyons initially defended wearing the $t$-shirt as an unintentional act and refused to apologise. He argued that he first bought the t-shirt in London when Madonna's coffee table book Sex came out in 1992, because he loved the photograph: "I have a great collection of pictures of both naked men and naked women, particularly naked women, and art right through my house - and through every museum around the world. So what do you do? Close all the museums because of the most beautiful human body?" (Tsvirko; Miletic). Lyons qualified his unintentional act via local, national and international media interviews saying it was: "A great picture and image of our time" (Mitchell). Lyons continued to protest that, until an Oktoberfest guest had raised the writing on the t-shirt with him, he had not realised the connotation of the words at the time of putting it on: "I came inside and looked at it and thought, 'Oh, right. Good point'" (Miletic; Badham).

Some local commentators supported Lyons and claimed that he had made a simple but stupid mistake: "It's just a t-shirt, no need to apologise for art" (Jean). One well-known local commentator, Paul Dyer, suggested that the media was driving the story and it was the biggest "toss story" of the year. In addition, there were suggestions that the attack on Lyons was politically motivated: "Excluding the ABC, Fairfax, NineMSN and Sky News, the Advertiser has no equal nationwide in its eagerness to stick the knife in the back of anything conservative and everything Darryn Lyons" (Davies 27). Nevertheless, the intensity of the media and community attention eventually forced Lyons to admit on live radio and national TV that he regretted wearing the t-shirt (Miletic; Badham).

\section{An Intentional Act}

"Very often what a celebrity has printed on their t-shirt can decide whether the shots get into the papers or not; of course, the stars are all too aware of that." (Lyons 139)

Overall, the media articles examined indicate that Lyons was framed as intentionally wearing the t-shirt. For example, an article by Geelong Advertiser journalist David Cairns suggested that Lyons purposefully wore the t-shirt as a publicity stunt in order to generate media dollars for himself: "Ka-ching!" (Cairns 5). Cairns also claimed that Lyons skilfully preprepared his arguments about the t-shirt to ensure maximum exposure: "Was wearing the Geelong mayoral robes to a new beer festival which he is privately backing provocative? And don't you think he knows that?" (Cairns 5). Cairns argued that Lyons has a "no publicity is bad publicity mantra" and that, as the "champion of free publicity" he intended to spread the message to the world via social media (Cairns 5). 
While Lyons protested it was a completely innocent mistake, some members of the local community demanded his resignation for demeaning Geelong's reputation. For example, a change.org petition titled: "wrong for Geelong - and wrong for everyone everywhere" called for Lyons to be sacked (Cannon; Miletic). The petition, with 476 signatures, argued that the message on Lyons's t-shirt promoted sexual violence against women. It called for Lyons to resign and argued that the t-shirt wording was: "A gross disregard for the families of those many thousands of people who have died while hitch-hiking" (change.org). Jackie Kriz, a member of the Nurses and Midwives Federation and of the Socialist Alliance also refused to accept that it was an unintentional act: "We know that appearance is very important to him" (Kriz 4). Social media commentators also questioned Lyons's excuses: "OK, even if this is true, if you can't read your own clothing then how are you qualified to lead a community?" (Miles). Another resident argued that Lyons was an "intuitive semiotician", and that his reported defence of the t-shirt incident lacked credibility (Sahr 27).

Lyons describes himself as "a Tory through and through" (Lyons 175) and argued that, as a Liberal mayor, he was being targeted by his Australian Labor Party (ALP) and Union opponents: "People want to use this as an excuse to bring down the mayor of Geelong" (Cannon 3 ). However, during his term of office, Lyons was notorious for publically venting his frustration with State and Federal politicians, and particularly ALP members, which made for a very fractious relationship between him and the Labor-run State Government (Squires). This example highlights how Lyons's celebrity persona did not appear to be very compatible with his public persona as mayor. Consequently, the local Unions attacked Lyons, with the Trades Hall Secretary calling for his resignation: "I think he does know (what it said) and he's had a boysy day on the beer" (Cannon 4). However, the Premier of the ALP-led State Government declined to comment on calls for Lyons's resignation: "He needs to explain what he was wearing and why. I'm not going to be drawn into that. I don't own a t-shirt like that, therefore I wouldn't wear one" (The Guardian). The Local Government Minister reminded Lyons that he was "supposed to represent the people of Geelong" and should act accordingly (Cannon 4). Nevertheless, the Minister advised that there was nothing in the Local Government Act about dressing respectfully.

Condemnation also came from the Liberal Party with the Federal member for Corangamite, Sarah Henderson, criticising Lyons's t-shirt as "totally inappropriate" (Cannon 3). But the majority of criticism came from ALP members, and the t-shirt incident was raised at the highest level by Richard Marles, the Federal Member for Corio, during his constituency statement in Parliament. Regional mayors also spoke out against Lyons's actions, particularly as he was Chairperson of the Geelong Region's Local Government Alliance (G21). Colac Otway Mayor Frank Buchanan argued that Lyons's actions had hurt the reputation of G21 and that, if he had acted as Lyons had, he would expect to be: "Pulled over the coals" (Cannon 3). However, G21's CEO, Elaine Carbines, dismissed Buchanan's claims and argued that the community could distinguish between Lyons's "inappropriate behaviour" and the work of G21 (Cannon 3). This is an interesting nuance as Carbines is a former ALP member of the Victorian State Parliament and, while Lyons was Chairman of G21, she dealt with both his politics and his behaviour.

Lyons's man of the people image, celebrity, and irreverence towards the mayoral role was a common theme in the analysed online comments. For example: "When you are mayor, you are mayor 24/7, and this is not how a mayor normally represents his city" (Cairns). In addition: "The one thing you cannot be [when you are a mayor] is up yourself. And, Darryn, mate, that is you" (Badham). More specifically, the dialogue overtook all discussion on the important issues facing Geelong, such as job losses: "Since he became mayor, the ugliness of 
what he chooses to spend his money on has more serious implications - because Geelong has been in trouble for a while" (Badham).

\section{CONCLUSION}

It is evident that, through the t-shirt incident, Lyons was framed negatively, which resulted in him being positioned as "intentionally" wearing the t-shirt. Although most online commenters examined here liked Lyons wearing the t-shirt and accepted the "unintentional" frame, it was the "intentional" frame that emerged strongest through the media commentary from data set one. This is despite the fact that the analysis undertaken of data set two showed that readers were mostly not as offended by the t-shirt incident. Although Lyons received positive comments supporting his "unintentional" claim, a majority of the Geelong Advertiser survey respondents disliked his action, and framed it as "intentional". They viewed it as a miscalculation by an elected official. Lyons's qualities were framed as being disrespectful of his mayoral role, and the legitimacy of local government was therefore undermined by him wearing the t-shirt.

Although I acknowledge Badham's associations with the Labor party, her commentary came closest to the core of the "intentional" versus "unintentional" question. More specifically, that the t-shirt incident seemed to remain the focus for Geelong- and not the important issues of the city. On this evidence, Lyons's actions indicate that his celebrity persona appeared to be conflicted with his public persona.

There is no doubt that Lyons's celebrity persona put Geelong on the global map. For good and bad reasons, the city had more exposure than before his election. The more outrageously Lyons behaved, it seems, the more people loved him and the "Trump factor" emerged in miniature (Squires). However, Lyons did not appear to successfully leverage his "zany or off-kilter" behaviour to the benefit of Geelong (Wood, Corbett and Flinders 591). It could be argued that the ironic effect of a "mohawk mayor" wearing a controversial t-shirt undermined rather than enhanced the legitimacy of local government, and this ultimately drowned out Geelong's important issues. Throughout his term of office, Lyons's celebrity persona seemed to draw continued criticism, and his mayoral term appeared to be marred by arguments rather than success. This was exactly the opposite of what Geelong needed in terms of a leader with a public persona capable of providing leadership and strategic direction. However, it can also be argued that Geelong's leadership structure was still in flux and Lyons had insufficient time to make much impact on governance, or the problems facing the city.

With other countries implementing, reviewing or considering directly elected mayoral models, further research is required to combine the literature on directly elected mayors and celebrity politics. There are shortcomings in the literature on directly elected celebrity mayors, and specifically those in Australian second-tier cities. These omissions limit the degree to which a satisfactory explanation of "celebrities making good mayors" has been provided. Greater examination will also help us understand if directly elected mayoral models improve engagement, and - combined - whether they make matters better, worse, or both better and worse. Further investigation of the Lyons case could shed light on how local governments can develop policies to manage future directly elected celebrity mayors. For example, six months after the t-shirt incident, the mayoral chain was transferred from Lyons's office to a locked safe in the CEO's office. This means that future mayors can no longer put on the formal regalia where and when they want to, and have to sign a register before using them (Squires).

As highlighted by Sansom, there is a growing belief that more effective leadership is needed in local government, and directly elected mayors could be seen as representative of a 
broader shift to address this issue. Celebrity is fast emerging as a serious issue within that process, especially as directly elected mayoral systems may open up greater opportunities for celebrity politicians. However, it remains unclear whether the system of elected office is deemed wrong if a celebrity can become mayor (Copus). Celebrities may or may not be more effective in the end but, as newcomers to politics, they can lack the skills needed to lead effectively. In Lyons's case, he appeared unable to effectively separate his celebrity persona from his public persona, which made it hard for him to successfully lead. As the Victorian State Government implements a new model of democracy for Geelong, the Lyons case is an important demonstration of the effects that directly elected celebrity mayors have on legitimacy and good governance.

\section{WORKS CITED}

't Hart, Paul, and Karen Tindall. "Leadership by the Famous: Celebrity as Political Capital." Dispersed Democratic Leadership: Origins, Dynamics, and Implications. Ed. John Kane, Haig Patapan and Paul 't Hart. Oxford: Oxford University Press, 2009. 255-78. Print.

Asquith, Andy. "A Bullock, a Monkey and Robocop: An Assessment of the Directly Elected Mayor in English Local Government." Policy \& Politics. 36 (2008): 39-53. Web. 9 June 2015.

Badham, Van. "Giddy up, Darryn Lyons. Geelong Needs More Than a Mayor on a Bender " The Guardian 2015. Web. 25 October 2015.

Barnett, Michael. "Culture, Strategy and Foreign Policy Change: Israel's Road to Oslo." European Journal of International Relations 5 (1999): 5-36. Print.

Boykoff, Maxwell T., and Michael K. Goodman. "Conspicuous Redemption? Reflections on the Promises and Perils of the "Celebritization" of Climate Change." Geoforum 403 (2009): 395-406. Print.

Cadart, Bertrand. "Bertrand Cadart Profile." 2015. Web. 9 March 2015.

Cairns, David. "Mayor at Happiest in Glare of Publicity." Geelong Advertiser 12 October 2015 2015: 5. Print.

---. "Mayor Darryn Lyons Kicks up a Storm with His Full Frontal T-Shirt." 2015. Web.

Campus, Donatella. Women Political Leaders and the Media. Basingstoke: Palgrave Macmillan, 2013. Print.

Campus, Donatella, and Gianfranco Pasquino. "How to Lose a Mayor: The Case of Bologna." Journal of Modern Italian Studies 5.1 (2000): 22-35. Print.

Cannon, Anthea. "Councillors Consider Action." Geelong Advertiser 13 October 2013 2015: 3. Print.

---. "Mayor's T-Shirt Fiasco Labelled as Sexist." Geelong Advertiser 12 October 2015 2015: 4. Print.

Casson, Rebecca. The Kent-Virginia Project: A Study of Local Government Paradiplomacy. LAP Lambert Acad. Publ., 2010. Print.

change.org. "Wrong for Geelong - and Wrong for Everyone, Everywhere." change.org October 2015 2015. Web. 5 August 20162016.

City of Greater Geelong. "100 Days of Action Cr Darryn Lyons Directly Elected Mayor City of Greater Geelong." Geelong: City of Greater Geelong, 2014. 1-30. Print.

Cohen, Josh. The Private Life. [Electronic Resource] : Our Everyday Self in an Age of Intrusion. Berkeley, CA : Counterpoint, 2015. Print.

Colquhoun, Steve. "What Is Geelong's Mayor Doing?" Sydney Morning Herald 19 February 2014 2014. Print.

Copus, Colin. "Directly Elected Mayors: A Tonic for Local Governance or Old Wine in New Bottles?" Local Government Studies 30.4 (2004a): 576-88. Print.

---. Party Politics in English Local Government Manchester: Manchester University Press, 2004b. Print. 
Davies, Greg "Political Storm over a T-Shirt." Ed. Advertiser, Geelong. Geelong: Geelong Advertiser, 2015. 27. Print.

Dollery, Brian, and Neil Marshall. Australian Local Government : Reform and Renewal. South Melbourne : Macmillan Education Australia, 1997., 1997. Print.

Dundas, Greg. "No Action over Mayor's Shirt." Geelong Advertiser 22 October 20152015. Print.

Dyer, Paul 'Chicken'. "The Biggest Toss Story of the Year." Facebook. 2015. Print.

Elcock, Howard. "Elected Mayors: Lesson Drawing from Four Countries." Public Administration 86.3 (2008): 795-811. Print.

Farrell, Jan. @CrJanFarrell "As a Woman Who Lives and Works in Geelong I Am Beyond Offended." Twitter 2015. Print.

Fenwick, John, Howard Elcock, and Janice McMillan. "Leadership and Management in Uk Local Government: A Role for Elected Mayors?" International Review of Administrative Sciences 72.3 (2006): 431-47. Print.

Game, Chris. "Elected Mayors: More Distraction Than Attraction?" Public Policy and Administration 18.1 (2003): 13-28. Print.

Goffman, Erving. The Presentation of Self in Everyday Life. Woodstock, New York : The Overlook Press, 1973., 1959. Print.

Grant, Bligh, Brian Dollery, and Jeff Gow. "Local Democarcy and Local Government Efficiency: The Case of Elected Executives in Australian Local Government." Australian Journal of Political Science 46.1 (2011): 53-69. Print.

Grant, Bligh, Roberta Ryan, and Andrew Kelly. "The Australian Government's' White Paper on Reform of the Federation'and the Future of Australian Local Government." (2015). Print.

Grant, Bligh, Brian Dollery, and Michael A. Kortt. "Is There a Case for Mandating Directly Elected Mayors in Australian Local Government? Lessons from the 2012 Queensland Local Government Elections." Australian Journal of Public Administration (2015). Print.

Hurley, David, and Andrew Jefferson. "Lyons Share: Geelong Ratepayers Foot Bill for Fancy Hotels and Fountain Pens " Herald Sun 2014. Web. 14 December 20142014.

Hyde, Lewis. Trickster Makes This World: Mischief, Myth and Art. New York: Farrar, Straus, and Giroux, 1998. Print.

Jean, Paul. @Jeano668 "@DarrynLyons Mate it is just a tshirt, no need to apologise for art." 11 October 2015, 14:26. Tweet.

Jung, Carl G. Two Essays on Analytical Psychology. Translated by R. F. C. Hull, Bollingen Series: 20: Princeton, N.J. : Princeton University Press, 1966. Print.

Kavanagh, Dennis, et al. British Politics. Oxford University Press, USA, 2006. Print.

Kriz, Jackie. "This Is Not Just About a T-Shirt, It's About Misogyny." Green Left Weekly 20 October 2015 2015. Print.

Kurmelovs, Royce "Australia Geelong: How Scandal Sank Paparazzo Mayor Darryn Lyons." BBC 13 April 2016. Web. 7 August 2016.

Lander, \& Rogers. "Darryn Paul Lyons and Brian Fowler." Melbourne: Lander and Rogers, 2014. Print.

Layard, John. "The Trickster: A Study in American-Indian Mythology." Journal of Analytical Psychology 2.1 (1957): 106-11. Print.

Leach, Robert, Bill Coxall, and Lynton Robins. British Politics. Palgrave Macmillan, 2011. Print.

Lyons, Darryn. Mr Paparazzi. London: John Blake Publishing Ltd., 2009. Print.

---. @DarrynLyons "Perfect day for Oktoberfest Geelong!!! Get down tiks on sale at the door Geelongracingclub now don't miss out!!!" 10 October 2015. Tweet.

Marles, Richard. "Domestic Violence." Ed. Constituency Statements, House of Representatives. Canberra: Commonwealth of Australia, 2015. 10862 Print.

Marsh, David, Paul 't Hart, and Karen Tindall. "Celebrity Politics: The Politics of Late Modernity?" Political Studies Review 8.3 (2010): 322-40. Print.

Marshall, P David. Celebrity and Power: Fame in Contemporary Culture. U of Minnesota Press, 1997. Print. 
---. "The Promotion and Presentation of the Self: Celebrity as Marker of Presentational Media." Celebrity Studies 1.1 (2010): 35-48. Print.

---. Marshall, P. David. "Persona Studies: Mapping the Proliferation of the Public Self”. Journalism 15.2 (2014): 153-170. Print.

Martin, John, and Chris Aulich. Political Management in Australian Local Government: Exploring Roles and Relationships between Mayors and Ceos Sydney: Australian Centre of Excellence for Local Government, University of Technology Sydney, 2012. Print.

Metman, Philip. "The Trickster Figure in Schizophrenia." Journal of Analytical Psychology 3.1 (1958): 5-20. Print.

Miles, Joe. @Filter_Select "Ok, even if this is true, if you can't read your own clothing then how are you qualified to lead a community? Time to go bro." 11 October 2015, 8.22pm. Tweet.

Miletic, Daniella. "Geelong Mayor Darryn Lyons under Fire for Wearing a T-Shirt of a Naked Woman." The Age Victoria 2015. Web. 25 October 2015.

Millar, Royce. "Geelong Mayoral Election." The Age 13 November 2013 2013. Print.

---. "Old School Ties and Six Packs." The Age 13 November 2013 2013. Print.

Mitchell, Neil. "T-Shirt Outrage: Geelong Mayor Darryn Lyons Sorry for Faux Pas." 3AW 12 October 2015. Web. 1 August 2016.

Moffitt, Benjamin, and Simon Tormey. "Rethinking Populism: Politics, Mediatisation and Political Style." Political Studies 62.2 (2014): 381-97. Print.

Moore, Peter. "Once Bitten, Twice Shy Talk's Cheap from Would-Be Mayors." Geelong Advertiser 17 October 2013 2013. Print.

Mouritzen, Poul Erik, and James H Svara. Leadership at the Apex: Politicians and Administrators in Western Local Governments. University of Pittsburgh Press, 2002. Print.

Mukherjee, Jaideep. "Celebrity, Media and Politics:An Indian Perspective." Parliamentary Affairs 57.1 (2004): 80-92. Print.

New Democracy. "Democracy in Geelong." Geelong: New Democracy, 2016. Print.

O'Brien, Susie. "Geelong Mayor Darryn Lyons: Is T-Shirt Controversy Enough to Force Resignation?" Herald Sun 13 October 2015. Web. 1 August 2016.

Ostiguy, Pierre. "The High-Low Political Divide. Rethinking Populism and Anti-Populism." Committee on Concepts and Methods Working Paper Series 35 (2009). Print.

Papps, Nick. "Your Say, Your Opinion." Geelong Advertiser 13 October 2015: 16-17. Print.

Power, John M., Roger Wettenhall, and John Halligan. Local Government Systems of Australia. Canberra: Australian Govt. Pub. Service, 1981. Print.

Rallings, Colin, Michael Thrasher, and David Cowling . "Mayoral Referendums and Elections." Local Government Studies 28.4 (2002): 67-90. Print.

Rao, Nirmala. "Options for Change: Mayors, Cabinets or the Status Quo?" Local Government Studies 29.1 (2003): 1-16. Print.

Rojek, Chris. Celebrity. London: Reaktion, 2001. Print.

Sahr, Guenter. "Councillor's Chance to Show Mettle." Ed. Advertiser, Geelong. Geelong: Geelong Advertiser, 2015. 27. Print.

Sansom, Graham. Australian mayors: what can and should they do? Sydney: Centre for Local Government, University of Technology Sydney, 2012. Print.

Squires, Mandy. "Geelong Mayor Darryn Lyons' Mayoral Robes Locked Away with Ceo." Geelong Advertiser 2016. Web. 1 August 2016.

---. "Outspoken Geelong Mayor Darryn Lyons Will Leave a Colourful Legacy." Geelong Advertiser 2016. Web. 3 April 2016.

Stoker, Gerry. How Are Mayors Measuring Up. London, UK: Office of the Deputy Prime Minister, 2004. Print.

Street, John. "Celebrity Politicians: Popular Culture and Political Representation." British Journal of Politics and International Relations 6.4 (2004): 435-52. Print.

The Guardian. "Geelong Mayor Darryn Lyons Urged to Resign over Naked Madonna T-Shirt." The Guardian 2015. Web. 1 August 2016. 
Travers, Tony. "Decentralization London-Style: The Gla and London Governance." Regional Studies 36.7 (2002): 779-88. Print.

Tsvirko, Naomi. "'Do We Close Museums Because They Feature Beautiful Human Bodies': Mayor Darryn Lyons (Sort of) Apologises for Wearing a 'Sexist' Shirt Featuring a Naked Madonna Hitchhiking to a Beer Festival." Daily Mail 2015. Web. 1 August 2016.

Tucker, Doug. "Changing Practices and Conceptions of the Executive Function in Urban Government: The Greater Brisbane Experience." Australian Journal of Public Administration 53.4 (1994): 508-20. Print.

Turner, Graeme, Frances Bonner, and P David Marshall. Fame Games: The Production of Celebrity in Australia. Cambridge University Press, 2000. Print.

Urban, Rebecca. "Geelong Boy Comes to the Party." The Age 17 April 2004. Web. 7 August 2016.

Victoria State Government. "Commission of Inquiry into Greater Geelong City Council." Victorian State Government 2016. Web. 6 February 2016.

Warwick Commission. Elected Mayors and City Leadership. Coventry: University of Warwick, 2012. Print.

West, Darrel M , and John Orman. Celebrity Politics. Upper Saddle River, N.J.: Prentice Hall, 2003. Print.

Wheeler, Mark. Celebrity Politics. Polity, 2013. Print.

Wood, Matthew, Jack Corbett, and Matthew Flinders. "Just Like Us: Everyday Celebrity Politicians and the Pursuit of Popularity in an Age of Anti-Politics." The British Journal of Politics and International Relations 18 (3) (2016): 581 -98 Print.

Worthington, Andrew C., and Brian E. Dollery. "An Analysis of Recent Trends in Australian Local Government." International Journal of Public Sector Management 15.6 (2002): 496-515. Print.

Wright, Katharine A.M. and Jack Holland. "Leadership and the Media: Gendered Framings of Julia Gillard's 'Sexism and Misogyny' Speech." Australian Journal of Political Science 49.3 (2014): 455-68. Print. 